\title{
CACALOL ACETATE, A SESQUITERPENE FROM Psacalium decompositum, EXERTS AN ANTI-INFLAMMATORY EFFECT THROUGH LPS/NF-KB SIGNALING IN RAW 264.7 MACROPHAGES
}

Mora-Ramiro $\mathrm{B}^{\dagger}$, Jiménez-Estrada $\mathrm{M}^{\ddagger}$, Zentella-Dehesa $\mathrm{A}^{\S^{\wedge}}$, Ventura-Gallegos $\mathrm{JL}^{\S \wedge}$,

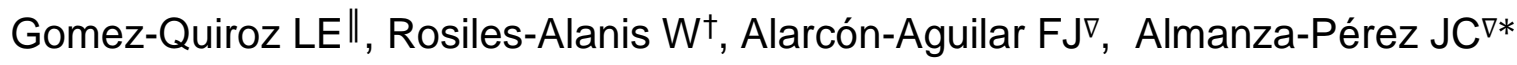

†Posgrado en Biología Experimental, Division de CBS, UAM-Iztapalapa. San Rafael Atlixco 186, Vicentina, Delegación Iztapalapa, C.P. 09340, Ciudad de México, México.

‡Departamento de Productos Naturales, Instituto de Química, UNAM. Circuito, Mario de La Cueva s/n, C.U., 04510 Ciudad de México, México.

§Programa Institucional de Cáncer de Mama, Departamento de Medicina Genómica y Toxicología Ambiental. Instituto de Investigaciones Biomédicas, UNAM. Circuito, Mario de La Cueva s/n, C.U., 04510 Ciudad de México, México.

^Unidad de Bioquímica, Instituto de Ciencias Médicas y Nutrición Salvador Zubirán. Vasco de Quiroga 15, Belisario Domínguez Secc 16, Tlalpan, 14080 Ciudad de México, México

\|Departamento de Ciencias de la Salud, CBS, UAM-Iztapalapa. San Rafael Atlixco 186, Vicentina, Delegación Iztapalapa, C.P. 09340, Ciudad de México, México. 
चLaboratorio de Farmacología, Departamento de Ciencias de la Salud, División de CBS, UAM-Iztapalapa. San Rafael Atlixco 186, Vicentina, Delegación Iztapalapa, C.P. 09340, Ciudad de México, México. 


\begin{tabular}{|l|c|}
\hline \multicolumn{1}{|c|}{ Contents } & Pages \\
\hline $\begin{array}{l}\text { Figure S1. }{ }^{1} \mathrm{H} \text { NMR spectrum of cacalol acetate in } \mathrm{CDCl}_{3} \\
(300 \mathrm{MHz}) .\end{array}$ & 4 \\
\hline $\begin{array}{l}\text { Figure S2. }{ }^{13} \mathrm{C} \text { NMR spectrum of cacalol acetate in } \mathrm{CDCl}_{3} \\
(300 \mathrm{MHz}) .\end{array}$ & 5 \\
\hline Figure S3. Cell functionality of cacalol acetate. & 6 \\
\hline
\end{tabular}




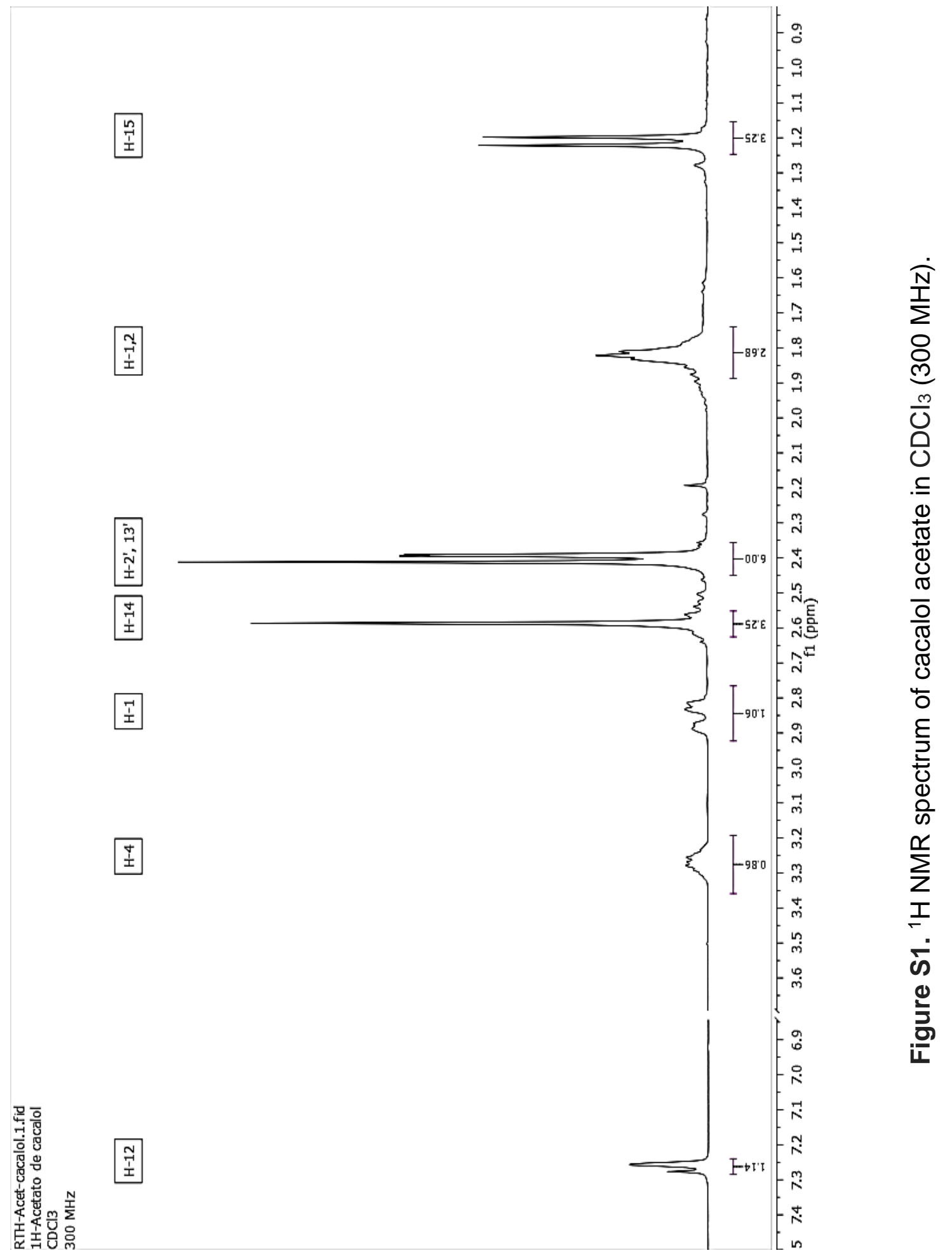




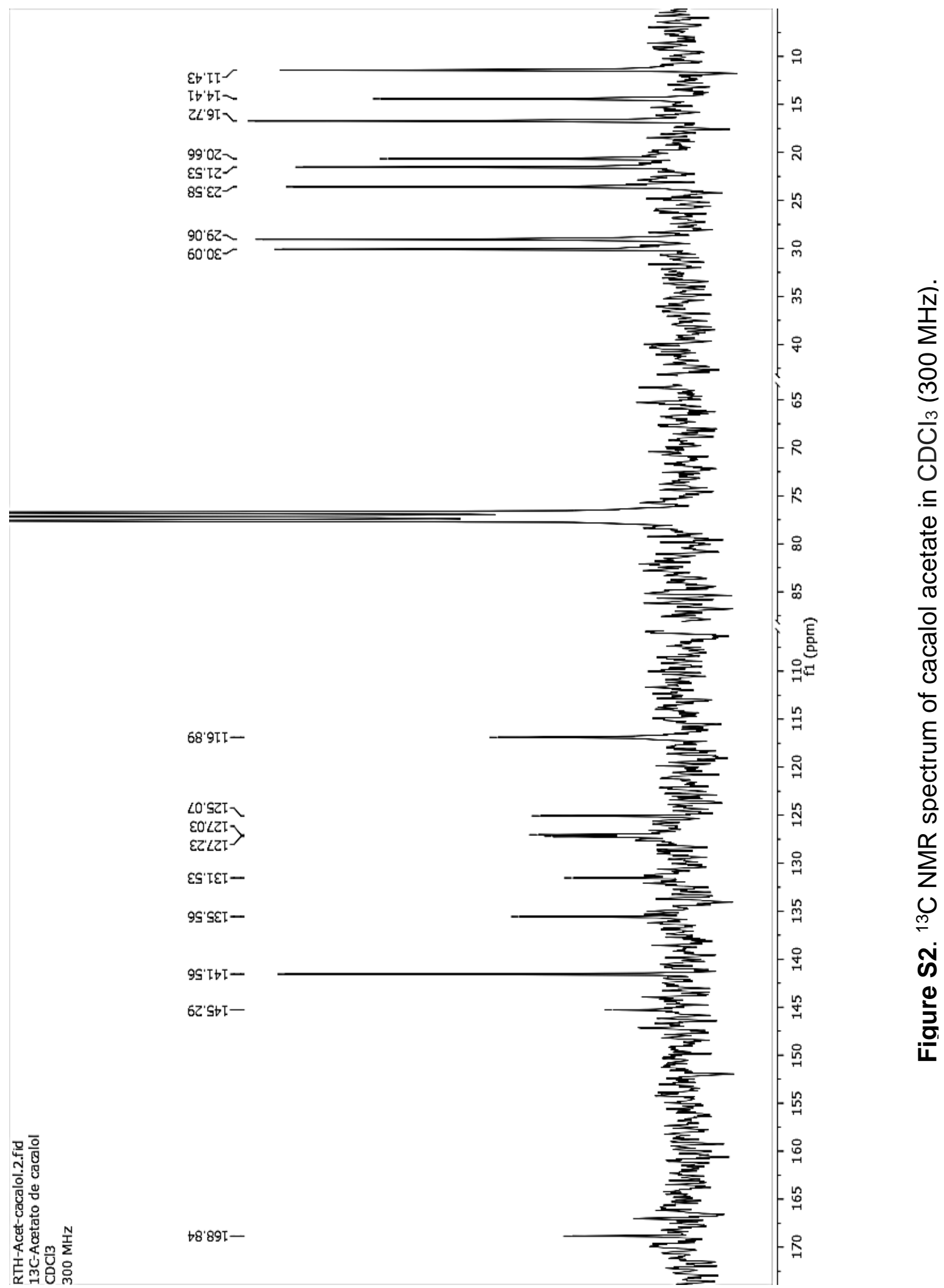




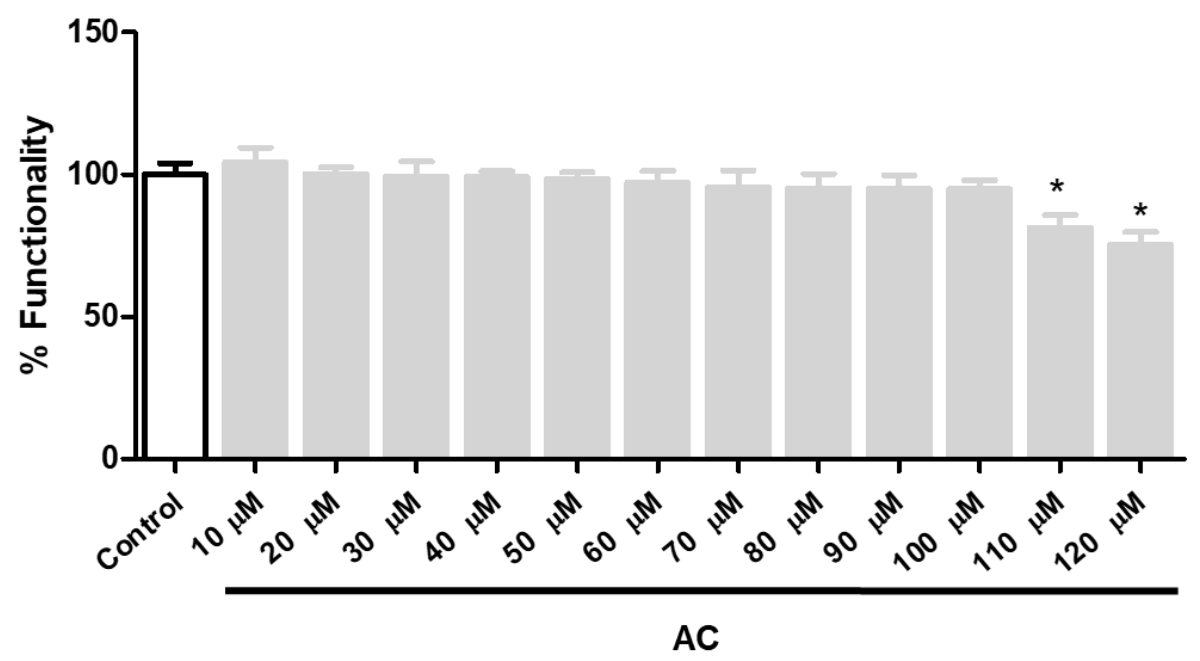

Figure S3. Cell functionality of cacalol acetate. Effect of different concentrations of CA on cell viability at $24 \mathrm{~h}$ of incubation in macrophages (Neutral red assay). Values are presented as means \pm SEM from six independent experiments. ${ }^{*} P<0.05$ compared to control. 